\title{
Obstetric complications in women with schizophrenia
}

\author{
Powikłania położnicze u kobiet chorych na schizofrenię \\ Małgorzata Futyma-Jędrzejewska ${ }^{1}$ A,B,C,F, https://orcid.org/0000-0002-3234-7901 \\ Ewelina Drzał²A,B, https://orcid.org/0000-0003-1247-1558 \\ Hanna Karakuła-Juchnowicz ${ }^{3}$ A,D, https://orcid.org/0000-0002-5971-795X \\ ${ }^{1}$ Prof. Mieczysław Kaczyński Neuropsychiatric Hospital in Lublin \\ ${ }^{2}$ Voivodeship Hospital for Neurotic and Psychiatric Patients in Suchowola \\ ${ }^{3}$ I Department of Psychiatry, Psychotherapy and Early Intervention, Medical University of Lublin
}

\begin{abstract}
Summary
Pregnancy, childbirth and motherhood are new situations for women and require adjustment. Women suffering from schizophrenia require special attention due to the course of the disease. Physiological changes that occur in the body during pregnancy may be unacceptable for women suffering from schizophrenia. They may delusively deny the existence of the pregnancy, lead an unhealthy lifestyle (stimulants, poor diet, lack of gynaecological check-ups), which in turn causes an increased risk of complications. In the research conducted so far, it has been proven that three kinds of complications are associated with schizophrenia: complications concerning pregnancy itself (bleeding, diabetes, Rh-incompatibility, pre-eclampsia), intrauterine growth restriction (low birth weight, congenital malformations, small head circumference) and complications regarding labour (uterine atony, asphyxia, emergency Caesarean section). The course of the labour itself in this specific group of patients has not yet been sufficiently examined. It has also been proven that perinatal complications are one of the factors determining an increased risk of schizophrenia.
\end{abstract}

Keywords: schizophrenia, obstetric complications, pregnancy, pre-eclampsia

\begin{abstract}
Streszczenie
Ciąża, poród i macierzyństwo to dla kobiety nowa sytuacja wymagająca odpowiedniego dostosowania. Kobiety chorujące na schizofrenię, ze względu na przebieg choroby wymagają szczególnej atencji. Fizjologiczne zmiany, jakie zachodzą w organizmie w czasie ciąży, mogą być nieakceptowalne przez kobiety chorujące na schizofrenię, mogą one urojeniowo zaprzeczać istnieniu ciąży, prowadzić niezdrowy tryb życia (używki, niewłaściwa dieta, brak kontrolnych wizyt ginekologicznych), co w konsekwencji powoduje, że ryzyko powikłań rośnie. W dotychczas przeprowadzonych badaniach udowodniono, że ze schizofrenią powiązane są 3 rodzaje komplikacji porodowych: komplikacje dotyczące samej ciąży (krwawienie, cukrzyca, niezgodność w zakresie czynnika Rh, stan przedrzucawkowy), nieprawidłowy wzrost wewnątrzpłodowy (niska masa urodzeniowa, wrodzone malformacje, zmniejszony obwód główki) oraz komplikacje dotyczące rozwiązania ciąży (atonia macicy, asfiksja, nagłe cięcie cesarskie). Sam przebieg porodu, u tej specyficznej grupy pacjentek nie został jeszcze dostatecznie zbadany. Udowodniono także, że komplikacje okołoporodowe stanowią jeden z czynników warunkujących zwiększenie ryzyka zachorowania na schizofrenię.
\end{abstract}

Słowa kluczowe: schizofrenia, powikłania położnicze, ciężarna, stan przedrzucawkowy

\section{Introduction}

Pregnancy, and then childbirth and motherhood are new situations for every woman that require proper preparation and adjustment [1]. There are many changes in the emotional and physiological spheres occurring at the same time triggered by hormones. The individual approach to this event depends on many factors, including the age of the woman, her family and professional situation, current life plans, level of maturity, emotional adjustment and personality structure [2], as well as co-morbid diseases, especially chronic ones. Schizophrenia concerns mainly 
young people in the reproductive age $[3,4]$, who require comprehensive assessment, treatment and additional health services related to their current life situation. The highest incidence of this disease is in women during the reproductive period. It is well known that the course of the disease can have a significant impact on the patient's cooperation with the obstetrician during labour, hence the pregnancy of a woman suffering from schizophrenia is a special challenge not only for the psychiatrist.

\section{Purpose and Method}

The purpose of this article is to review literature on obstetric complications in women with schizophrenia. This work evaluates the available publications on the topic using the Google Scholar electronic database and the recommendations of the Polish Society of Gynaecologicist and Obstetricians (Polskie Towarzystwo Ginekologiczne - PTG). The time descriptor was used: January 2000 - June 2018 and keywords: schizophrenia, obstetric complications, pregnancy, pre-eclampsia.

\section{Factors influencing the pregnancy in women suffering from schizophrenia}

During the physiological pregnancy there are many adaptive changes in the woman's body that are necessary to ensure optimal conditions for development and growth of the fetus [5]. These changes can be systematized in the following categories: anatomical, physiological and biochemical or as systemic changes, natural physical changes as well as natural emotional/psychological changes [6]. The discussed changes in the body of the pregnant woman concern: the circulatory system (hemodynamics and hematology), changes in the respiratory system, gastrointestinal tract, skeletal system, urinary tract, endocrine glands and metabolism [5-21]. Many of them may be unacceptable or incomprehensible to a pregnant woman suffering from schizophrenia [22]. The fertility rate (number of children born per woman in the childbearing age of 1549) in Poland in 2016 was 1.36 children, while in 2000 it was slightly more - 1.37 [23]. In 2017, upward trends were still observed [23], but the statistical data on the fertility of women with schizophrenia are inconclusive and only partially explain schizophrenia cases prevailing despite the women having fewer children [24]. In the Finnish study, increased fertility was found among the siblings of people suffering from schizophrenia, but it turned out that it did not compensate for a smaller number of children the patients had [24]. It was also shown that there is no significant difference between the delivery in women who had given birth before and after the first admission to the psychiatric ward [25]. Currently, it is known that female gender is a factor delaying the average age of schizophrenia $[26,27,28]$. The course of schizophrenia in women is also different than in men. Women have shorter stays in hospital and are hospitalized less frequently compared to men [22]. Researchers based their idea on the beneficial effects of estrogen hormones on the reduction of psychotic symptoms and their protective action in delaying the onset of the disease in women [29, 30,31]. American research conducted in 2005 showed that in many cases women suffering from schizophrenia had lower estrogen values than healthy women [32]. It was also found that women are more likely to fall ill or relapse during a period of their life associated with the decline of these hormones, i.e. in the period after childbirth and the perimenopausal period [33]. According to statistical data, women in general show a higher incidence of symptoms of mental disorders in the perinatal period [34], but psychotic symptoms that reveal themselves during pregnancy are rather rare [29]. Among the predisposing factors there are: the presence of psychotic symptoms in a previous pregnancy, pre-existing psychotic symptoms, mood disorders, the occurrence of psychotic symptoms during pregnancy in other women in the family [29]. There is a $10 \%$ to $15 \%$ risk that children of schizophrenic women will also be ill. This is supported by additional factors such as: lack of sufficient parental care, the effectiveness of medication in the prenatal period and obstetric complications [22]. It was also found that children of mothers with hypertension during pregnancy and those treated with diuretics in the third trimester had an increased risk of developing schizophrenia [35]. It should also be noted that diuretics do not show teratogenic effects, but their use during pregnancy is still controversial [35]. The reproductive functions in the course of schizophrenia are not disturbed $[29,36]$, but the course of the disease can lead to social withdrawal, difficulties in building close relationships with other people, or in building permanent relationships [36]. In the course of the disease, women can negate the existence of the pregnancy and it may be difficult to diagnose this while they are experiencing psychosis [22]. Mentally ill women are much less likely to seek medical care during pregnancy compared to women from a healthy population. In the case of ill women, the pregnancies are much more often unplanned and unwanted. Quite often, they are also victims of violence during the pregnancy [22]. Pregnant psychiatric patients may also delusively deny the existence of pregnancy. Psychotic experiences can lead to the rejection of medical care, difficulties in recognizing the start of labour and (rarely) to the killing of the newborns [22]. Women suffering from schizophrenia can lead an unhealthy lifestyle while being pregnant by: having an inappropriate diet, using stimulants (cigarettes, alcohol, 
drugs) and by lack of proper obstetric care, preventive measures (using folic acid supplementation) and laboratory control tests (e.g. towards anaemia, gestational diabetes) and ultrasonic examinations [37]. A large percentage of the ill are addicted to nicotine. According to some sources, it is from $74 \%$ to even $92 \%$. Women are also addicted to nicotine and, most often, they do not cease their addiction during pregnancy [22]. It turned out that women suffering from schizophrenia less frequently participated in gynaecological visits concerning prenatal care [25], which may have huge consequences for the fetus. Another important risk factor for women with schizophrenia is an increased risk of suicide attempt [38]. In Poland there are currently no programs for caring for a pregnant mentally ill woman. Also within the framework of rehabilitation programs for the ill there are no psychoeducational modules nor skills trainings related to the use of contraceptives, sexual behaviour, childcare or starting a family [22]. In 2011, a meta-analysis of studies was carried out [39], which lists the risk factors affecting the course of pregnancy, the delivery and the complications for a child and mother. These are: smoking, increased age of the patient, discrimination, unplanned pregnancy, exposure to medicines during pregnancy, late pregnancy detection, poor attachment of the woman to the developing fetus, insufficient prenatal care and other co-morbidities. It is also known that women suffering from schizophrenia experience more stress and anxiety compared to healthy women, especially when it comes to the fear of losing a child [40].

\section{Parturition in women suffering from schizophrenia}

Braxton Hicks contractions (sometimes occurring at 2-3 weeks before delivery) require differentiation from true labour contractions $[9,41]$, because they may be misinterpreted as nonspecific abdominal pain. About 75$85 \%$ of women give birth spontaneously within 24 hours of spontaneous rupture of membranes after 36 weeks of pregnancy [41] - currently there is no data regarding this percentage in women suffering from schizophrenia. Preinduction of labour (mechanical dilatation of the cervical canal using the Foley catheter) precedes induction and increases the chance of its success [41]. However, the frequency of this procedure in women suffering from schizophrenia has not been studied so far. The induction of labour is aimed at giving birth by natural forces by stimulating the uterine contraction function before the spontaneous beginning of labour [41, 42, 43]. According to PTG recommendations, induction of labour is considered as a method of treatment in cases when the benefits of a fast completion of pregnancy outweigh the risk associated with its continuation and the benefits of potential risk to the mother and the fetus should always be compared [43, 44]. The Australian cohort study published in 2016 shows that women $(\mathrm{N}=222)$ with severe mental disorders, including psychoses, required the use of labour induction much more often compared to women in the control group [45, 46]. The procedure of inducing labour in patients suffering from schizophrenia was used much more often for obstetric reasons than psychiatric ones (40\% vs. 15\%) [45]. The most common method of pharmacological induction of labour is oxytocin administration [41]. The current state of knowledge regarding the role of the oxytocynergic system and fluctuations in oxytocin concentration used to induce labour for the development of psychotic symptoms does not allow to sufficiently clear all doubts [46]. Therefore, it is recommended to avoid the use of oxytocin receptor ligand preparations in women with a history of psychotic disorders [47]. The infusion of oxytocin is associated with rapid growth followed by a cascade decrease in the concentration of this hormone [46]. When the puerperium begins, the concentration of corticotrophin (CRF), estrogen and progesterone increases dramatically [46]. In such a situation there is an increased risk of developing mental disorders [46]. For educational and practical reasons, the labour is divided into four stages. Based on the recommendations of PTG, in the first and second stage of labour in women suffering from illnesses that may affect the child's condition and in the event of abnormal labour (due to the ability to quickly perform obstetric surgery or Caesarean section ending labour) the presence of a doctor is necessary during spontaneous labour [41]. Prolongation of the second stage of labour may promote intrauterine hypoxia, trauma to the genital tract during labour and disturbance of the uterine contraction after delivery, and shortening the intervals between contractions may lead to foetal hypoxia [41]. This is why the patient's cooperation with the midwife or obstetrician is so important during this stage of labour. Routinely, perineal protection is also recommended at this stage of labour [41]. Currently, there is no data on the prevalence of episiotomy in women suffering from schizophrenia. At the initial placental period, the concentration of PGF $2 \alpha$ and PGE2 prostaglandin metabolites increases, which are partially responsible for postpartum myometrial contractions. According to the currently valid guidelines, in the active management of the third stage of labour, it is recommended to use anticoagulants: oxytocin (first choice drug), carbetocin (works more efficiently, faster and longer than oxytocin in cases of subatonia or uterine atony) and ergot alkaloids (rarely used because of side effects) [41]. Immediately after delivery (IV stage), the patient's general condition (blood pressure, heart rate, 
temperature), uterine contraction status and continuity of the uterine canal tissue are assessed [41]. The patient should stay within the delivery area, because in these first hours there is the greatest risk of hemorrhage [41]. The patient should be informed about the need to report increased bleeding from the genital tract [41]. Therefore, patients with schizophrenia who do not cooperate with the obstetric staff seem to require special supervision. In addition, the lack of cooperation can significantly increase the risk of complications for the child.

\section{Obstetric complications of women suffering from schizophrenia}

Perinatal complications are all events that interfere with the normal course of labour.

Many studies have confirmed that obstetric complications are more frequent in women with schizophrenia than in the general population [48-54]. This applies to both complications of the course of pregnancy and labour $[24,55,56]$. These studies also indirectly support the assumption that the unpredictable behaviour of a patient who is in psychosis during labour can complicate its course [57]. It has also been proven that perinatal complications are one of the factors conditioning an increased risk of schizophrenia [55, 58]. In addition, it was shown that the pregnancy of women who were previously treated for psychosis carries twice the risk of complications of pregnancy and labour, mainly in the area of premature delivery and low birth weight of the newborn [59]. The research also confirmed that obstetric complications are more common in natural siblings of patients suffering from schizophrenia [48]. In the studies cited earlier by Sacker et al., the risk of obstetric complications (OCs) during labour was higher when the mother had schizophrenia than when the father suffered from it [57].

In 2002, a meta-analysis of studies was carried out, in which it was confirmed that 3 kinds of childbirth complications are significantly associated with schizophrenia:

1. complications regarding pregnancy itself: bleeding, diabetes, Rh-incompatibility, pre-eclampsia

2. intrauterine growth restriction: low birth weight, congenital malformations, small head circumference

3. complications related to labour: uterine atony, asphyxia, emergency Caesarean section [60].

In a study of 29 probands based on the McNeil-Sjostrom Scale (assessment scale of obstetric complications), it was shown that bleeding during pregnancy, prolonged labour, problems with pregnancy, respiratory distress in newborns, delivery with forceps, emergency Caesarean section, breech position of the fetus, early gestational age during labour, extreme prematurity, low birth weight were the most common obstetric complications found in women with schizophrenia [61]. In another Australian study, an increased incidence of placental defects, antepartum haemorrhages, haemorrhaging during labour, and foetal hypoxia was found [62].

\section{Complications regarding the course of pregnancy itself}

\section{Bleeding}

Bleeding during pregnancy can have many causes. Implantation bleeding and shortened menstrual periods as well as miscarriages are common in the first month of pregnancy [60]. Miscarriages can be divided due to the severity of symptoms into the following: threatened miscarriage, inevitable abortion and missed miscarriage. Their cause can be explained after anatomical examination, hormonal examination, detecting infection and metabolic disorders, and genetic or autoimmune factors $[9,60]$. Other causes include trauma to the genital tract, start of labour and co-morbid tumour of the genital tract [63], multiple pregnancy, hypertension during pregnancy (preeclampsia, eclampsia, HELLP), chorionamnionitis, polyhydramnios, foetal death, anaemia, multipara 5 pregnancies, uterine fibroids, history of haemorrhage, obesity (less significant) [64]. In women with schizophrenia, bleeding from the placenta praevia ( $22 \%$ of causes of bleeding) and premature placental abruption (in the case of normally situated placenta - 31\%) are common in the second and third trimesters of pregnancy, especially in the last month [60]. The causes of bleeding in the middle pregnancy are much less understood than those occurring at the beginning or at the end [60]. In one of the studies, $2 / 3$ of the bleeding episodes of this pregnancy period occurred during premature placental abruption, placenta praevia, hydatidiform mole, cervical incompetence or other identified causes, while $1 / 3$ of cases were not completely determined [65]. In a few cases, the bleeding was due to foetal pathology with hypoxia, but in the vast majority the bleeding volume was small $[66,67]$.

\section{Preeclampsia}

Preeclampsia and eclampsia are a group of specific symptoms that are observed after the 20th week of pregnancy, during labour or puerperium, characterized by elevated blood pressure (pregnancy blood pressure increase $\geq 140 / 90 \mathrm{~mm} \mathrm{Hg}$ ), which is accompanied by significant proteinuria (loss $\geq 300 \mathrm{mg}$ proteins daily) [68]. Eclampsia 
is characterized by the preeclampsia of tonic-clonic convulsions associated with loss of consciousness, which have no other cause than gestational hypertension $[68,69]$. Thrombocytopenia (platelet count $<100,000 / \mathrm{mm} 3$ ) and hepatic enzymes activity increase [68], creatinine increase above $1.2 \mathrm{mg} / \mathrm{dl}$ (in cases when it was not previously elevated), headache, blurred vision, epigastric pain nausea and vomiting may occur [69]. Particular attention was paid to preeclampsia in 1996, when Kendell et al. confirmed a considerable link between preeclampsia and subsequent schizophrenia $[60,70]$. Repeated analysis did not confirm such a significant role of preeclampsia, but a subsequent large population study showed that it is the only obstetric risk factor among other potential factors for the development of schizophrenia in a child [71]. The most popular theory currently combines the mechanism of impaired blood flow in the fetus with chronic hypoxia or malnutrition [60], but inflammatory changes are also taken into account. Future neuroimaging studies can provide important information on the impact of preeclampsia on the foetal brain $[72,73]$.

\section{Incompatibility of the $\mathrm{Rh}$ factor}

Autoimmune mechanisms may also affect the relationship between incompatibility of the Rh factor and subsequent schizophrenia [74, 75]. Haemolytic disease of the newborn is a neurological disorder whose secondary consequences may lead to early spontaneous abortion, chronic foetal hypoxia, neonatal asphyxia, pulmonary edema, hyperbilirubinemia of the newborn and kernicterus [74, 76]. Rh factor incompatibility is an example where maternal recognition and sensitization to foetal cells (RBC) presenting antigen can lead to the production of immunoglobulin G, which when passing through the placenta lead to lysis of red blood cells [51]. It turned out that non-compliance with the Rh factor may lead to foetal hypoxia and indirectly affect the course of pregnancy and labour as well as cause more frequent occurrences of brain structure disorders in children of women suffering from schizophrenia [77].

\section{Gestational diabetes}

The relationship between diabetes and pregnancy and subsequent schizophrenia, although very strong, is based only on the analysis of several studies $[60,78,79]$. A study carried out by Schaefer et al. [78] indirectly confirms that increased body weight in a pregnant woman raises the risk of schizophrenia in the offspring. Moreover, it has been shown in this study that poorly controlled gestational diabetes increases the risk of congenital malformations, intellectual impairment and psychomotor development. It also turned out that insulin-dependent diabetes are more common among first-degree relatives of patients suffering from schizophrenia compared to healthy people, what may suggest the involvement of autoimmune factors [60, 80, 81]. The mechanism in which gestational diabetes would increase the risk of schizophrenia includes interactions between the intrauterine environment triggered by maternal hyperglycaemia and genetic susceptibility of the fetus [78].

Complications related to intrauterine growth restriction.

\section{Low birth weight}

Many studies have confirmed the relationship between low birth weight and schizophrenia [60, 82, 83].

But this relationship is not fully established [49, $84,85,86]$, which is mainly related to the large span of the child's body weight taken into account in the study. Low birth weight can most often be caused by premature birth or intrauterine growth retardation [87]. Using the quantitative approach, Wahlbeck et al. found that the risk of schizophrenia decreases in a linear way with the increase in body weight, increase in the birth length of the body and increase in placental mass (normally about 500g) [87]. Low birth weight and reduced body length increased the risk of developing schizophrenia [87]. In the meta-analysis of the research carried out in 2002, it was demonstrated that the risk of developing schizophrenia is rather dependent on intrauterine growth retardation [88]. A similar opinion was made in another study, suggesting that the small size of the placenta and late pregnancy maternal low body weight may be reflected in malnutrition of the fetus [87]. From the above comparison, it is also known that women who already have schizophrenia or fall ill later belong to a group of people with risky behaviours such as smoking, using drugs and poor participation in obstetric checkups, i.e. risk factors that may result in low birth weight [60]. In a repeatedly cited study conducted after the flu epidemic in Finland, the relationship between increased incidences of schizophrenia in the children of mothers in the second trimester of pregnancy has been proven [89]. A lot of studies have confirmed a similar increase in cases of upper respiratory tract infection, genital tract infections, rubella, Toxoplasma gondii, and herpes simplex virus type 2 [89]. In addition, low birth weight, preeclampsia, the need for an incubator after birth, the necessity of using forceps during labour, and psychoses in the family were associated with an earlier age at onset of psychosis (AOP). The use of forceps and birth weight are variables that best predict AOP in the first episode of psychosis (FEP). Stimulants, which were most commonly used together with marijuana and cocaine, were the only substances associated with the earlier AOP [90]. 


\section{Congenital malformations}

The vast majority of congenital defects that were evaluated in the meta-analysis of 2002 belong to minor physical anomalies (MPAs) [60, 91, 92]. The study by Thomas et al. [93] confirmed the increased occurrence of brain structure disorders in the children of women with schizophrenia who experienced obstetric complications during labour, especially prolonged delivery and injuries experienced during pregnancy and delivery. Small physical abnormalities were found most frequently in the area of the head: eyes, lips, ears but also the hands, feet and other parts of the limbs [94]. The brain disorders in these children were primarily related to the reduction of the left hippocampus, enlargement of the left lateral ventricle of the brain and the third chamber $[93,95]$. It was also reported that the dilatation of furrows and cortical slits was suggested, which may suggest the occurrence of a mild degree of diffusion volume decrease in these areas. In addition, there was a reduction in frontal lobes and smaller volume of grey matter in the hippocampus and temporal lobes $[93,96,97]$.

\section{Small foetal head circumference}

The head circumference of a newborn baby is a commonly used measurement for an approximate assessment of the condition of a newborn baby. Examination of the baby's head circumference (frontal-occipital circumference) is carried out with a sewing tape through the largest occipital convexity and the largest convexity of frontal eminence [98]. In a healthy, mature male newborn it is $35 \mathrm{~cm}$ (3-97th percentile: $33-37 \mathrm{~cm})$. It is larger by $1-2 \mathrm{~cm}$ from the chest circumference. For girls, it is $1-2 \mathrm{~cm}$ less. The values below the given standards are considered to be a smaller head circumference. It was also shown that the reduced birth weight and small head circumference (less than $31.5 \mathrm{~cm}$ ) were associated with the subsequent development of schizophrenia [99].

\section{Complications regarding the completion of pregnancy}

Mechanisms that lead to difficulties in carrying the pregnancy to term also caused a higher risk of hypoxia or anoxia in the fetus [60]. However, it is difficult to measure hypoxia levels, hence many studies were based on various definitions of these states [60]. In people with three or more obstetric complications combined with hypoxia, schizophrenia was five times more frequent compared to people without such complications [100]. The authors of these studies $[100,101]$ suggest that their results are consistent with a model for the development of schizophrenia combining genetic susceptibility with obstetric complications and that the neurotoxic effects of foetal asphyxia may lead to an earlier development of schizophrenia. Presumably complications combined with hypoxia may be associated with abnormalities in brain structure in patients with schizophrenia [102].

\section{Emergency Caesarean section and premature labour}

Indications for the completion of pregnancy may occur in both normal and pathological pregnancy due to maternal and/or foetal reasons [41]. The threat of preterm delivery as well as postterm delivery, from a psychological point of view, leads to unusually strong stress. The most dominating emotion is, of course, fear [37]. According to the current position of the Polish Society of Gynaecologists and Obstetricians, Caesarean section (cc) is an obstetric operation aimed at completing pregnancy or labour, when further waiting for its natural completion presents a danger for the mother and the child [103]. In the recommendations cited (referring to the analysis of Slomka et al.), the indications for Caesarean section were divided into 4 groups depending on the urgency of the operation: elective (planned) indications, urgent, emergency and crash [104]. Among the elective indications for the Caesarean section there were also non-osteogenic causes: cardiological, ophthalmic [105], orthopedic, neurological and psychiatric [103]. The latter, according to the authors, are the most controversial and rare non-obstetric indications [103]. Most often they concern the failure to accept childbirth by forces of nature and the attitude of anxiety towards delivery [103]. Gynecologists stress that many of such indications should be treated critically and considered as a time indication, which may be subject to verification during effective psychotherapy and pharmacotherapy as well as the acquisition of knowledge about labour at birth classes [103]. Despite the controversial psychiatric indications, Caesarean delivery has not been thoroughly discussed [46]. It is also not taken into account which of the mental disorders may constitute an absolute or relative indication for Caesarean section [46]. According to data from the Polish psychiatric and gynaecological literature, the scope of psychiatric disorders, whose occurrence in a pregnant woman could result in a delivery by Caesarean section, could not be precisely specified. In each case psychiatric indications for Caesarean section should be considered individually [46]. The decisive criterion should be the potential cooperation of the patient with obstetric staff during the natural birth [46]. Currently, there are no data on the number of births carried out in Poland in patients with a history of mental illness. There are also no statistics on the forms of delivery in 
such patients [46]. On the basis of literature data, two types of psychiatric indications can be distinguished for solving a pregnancy through Caesarean section [46]. The first group of indications concerns patients with a history of psychiatric disorders or observed change of behaviour during the course of mental illness during the whole pregnancy or in the period directly preceding labour [46]. Unadjusted behaviour of such patients may raise many doubts among obstetricians regarding cooperation during childbirth and it seems obvious to determine the level of cooperation with the severity of mental disorders [46]. Delivery by Caesarean section may improve the control of labour and thus prevent the development of perinatal complications resulting from the prolongation of subsequent labour stages during inadequate cooperation from the mother or sudden exacerbation of mental disorders in the perinatal period [46]. The second group of indications concerns increased fear of childbirth (tokophobia) [46]. The literature has not yet characterized the forms of tokophobia, which can be effectively reduced by psychoeducation or psychotherapeutic interventions [46]. In 2013, the guidelines of the National Institute of Health and Care Excellence (NICE) on the nature of tokophobia were published in the United Kingdom, suggesting it would be an indication for delivery by Caesarean section [106]. According to the above-mentioned standards, every pregnant woman who reports symptoms of fear of childbirth should be consulted by a specialist in the field of mental health, pregnancy and puerperium. Before the consultation, she should be able to discuss all medical indications regarding the delivery by both methods [106]. If after a series of psychoeducational meetings the patient with symptoms of fear of childbirth still does not agree to delivery with the forces of nature, according to the NICE guidelines, the pregnancy should be completed by Caesarean section $[106,107]$. In Poland, for this purpose, psychoeducational programs are used in antenatal schools [106]. In the available Polish literature, there are no data on the preferred methods of delivery in women with severe mental disorders (including schizophrenia or bipolar disorder) [46].

\section{Placenta praevia and premature separation of the normally situated placenta}

In many reports, the relationship between obstetric complications and schizophrenia has been confirmed [108]. Since only a few years, special attention has been given to placental pathology, binding it to intra-lateral brain injury [109] and cerebral palsy [110]. The placenta produces many important substances for the developing brain, such as serotonin [111] or other monoamines, [63] and vasoactive intestinal peptide [102]. Psychiatric complications can only be revealed years later [109], which has been proven so far in the case of an increased risk of cerebral palsy [94]. Studies on animals have shown an even greater role of placenta in supporting foetal brain development when the mother has an eating disorder and in the case of stress, which could increase catabolism of the placenta carrying "fuel" for foetal brain through programmed gene expression [112]. The placenta is normally only histopathologically examined if the disease was diagnosed in the child during delivery [41, 113]. One of the studies confirmed that the placenta praevia and premature separation of the normally situated placenta are a more frequent cause of obstetric complications in women with schizophrenia [39], while in another study such a significant influence between the control group was not confirmed ( $1 \%$ versus $4 \%, p=0.333$ and $1 \%$ versus $0.7 \%$, $\mathrm{p}=0.51)[114]$.

\section{Other complications}

Other complications regarding the pregnancy of women with schizophrenia have not been studied so far. This applies first of all to: uterine rupture, septic shock in septic abortion, amniotic sac rupture, umbilical cord prolapse, vesicovaginal fistula, cervical fissure, vulvar damage, injury to the pubic symphysis and perone buccal bone as well as vulvar, perineal and vaginal hematoma.

\section{Conclusions}

Pregnant patients suffering from schizophrenia are a specific group of patients. Caring for them during pregnancy requires a holistic approach. It is well known that the risk of perinatal complications is much higher among them than in the general population. The presented analysis certainly did not exhaust the possible dilemmas and problems that may be encountered by medical personnel. However, it can definitely develop a thread of understanding between a psychiatrist and a gynecologist. Difficulties that may occur during the treatment of this specific group of patients will continue to be quite the therapeutic challenge for doctors and nurses. 


\section{Wstęp}

Ciąża, a potem poród i macierzyństwo to dla każdej kobiety nowa sytuacja, wymagająca odpowiedniego przygotowania i dostosowania [1]. W tym czasie dochodzi do wielu przemian dotyczących sfery emocjonalnej i fizjologicznej, wyzwalanych pod wpływem hormonów. Indywidualne podejście do tego wydarzenia zależy od wielu czynników, w tym od wieku kobiety, jej osobistej sytuacji rodzinnej i zawodowej, aktualnych planów życiowych, poziomu dojrzałości, przystosowania emocjonalnego oraz struktury osobowości [2], a także chorób współistniejących, szczególnie przewlekłych. Schizofrenia dotyczy głównie osób młodych, w wieku rozrodczym [3, 4], które wymagają kompleksowej oceny, leczenia oraz dodatkowych świadczeń zdrowotnych związanych $\mathrm{z}$ aktualną sytuacją życiową. Okres największej zapadalności na tę jednostkę chorobową przypada u kobiet w okresie prokreacyjnym. Powszechnie wiadomo, że przebieg choroby może mieć istotny wpływ na współpracę pacjentki z położnikiem podczas porodu, stąd ciąża kobiety chorującej na schizofrenię jest szczególnym wyzwaniem nie tylko dla psychiatry.

\section{Cel i Metoda}

Celem niniejszego artykułu jest przegląd literatury dotyczącej problematyki powikłań położniczych u kobiet chorujących na schizofrenię. W niniejszej pracy dokonano oceny dostępnych publikacji dotyczących poruszanego tematu wykorzystując elektroniczną bazę danych Google Scholar oraz rekomendacje Polskiego Towarzystwa Ginekologicznego (PTG). Użyto deskryptora czasowego: styczeń 2000 - czerwiec 2018 oraz słów - kluczy: schizofrenia, powikłania położnicze, ciężarna, stan przedrzucawkowy.

\section{Czynniki wpływające na przebieg ciąży u kobiet chorujących na schizofrenię}

Podczas ciąży fizjologicznej w organizmie kobiety zachodzi wiele zmian adaptacyjnych koniecznych do zapewnienia optymalnych warunków rozwoju i wzrastania płodu [5]. Zmiany te można usystematyzować w kategoriach: anatomicznych, fizjologicznych oraz biochemicznych lub jako zmiany ustrojowe, naturalne zmiany fizyczne, a także naturalne zmiany emocjonalne/psychologiczne [6]. Omawiane zmiany zachodzące w organizmie ciężarnej dotyczą: układu krążenia (hemodynamiki i hematologii), zmian w układzie oddechowym, przewodzie pokarmowym, układzie kostnym, drogach moczowych, gruczołach wydzielania wewnętrznego oraz metabolizmie [5-21]. Wiele z nich może być nieakceptowalna lub niezrozumiała dla ciężarnej chorującej na schizofrenię [22]. Współczynnik dzietności (liczba urodzonych dzieci przypadających na jedną kobietę $w$ wieku rozrodczym 15-49 lat) wyniósł w 2016 r. w Polsce 1,36 dziecka, podczas gdy w 2000 r. było to nieznacznie więcej, bo 1,37 [23]. W 2017 r. nadal obserwowane były tendencje wzrostowe [23], ale dane statystyczne dotyczące problemu dzietności kobiet chorych na schizofrenię są niejednoznaczne i tylko częściowo tłumaczą utrzymywanie się zachorowań na schizofrenię na stałym poziomie pomimo zmniejszonej ilości posiadanych dzieci [24]. W badaniu fińskim stwierdzono zwiększoną płodność wśród rodzeństwa osób chorych na schizofrenię, ale okazało się, że nie kompensowała ona mniejszej liczby dzieci u osób chorych [24]. Wykazano także, że nie ma znaczącej różnicy pomiędzy rozwiązaniem ciąży u kobiet, które urodziły przed i po pierwszym przyjęciu do oddziału psychiatrycznego [25]. Aktualnie wiadomo, że płeć żeńska jest czynnikiem opóźniającym przeciętny wiek zachorowania na schizofrenię [26, 27, 28]. Przebieg schizofrenii u kobiet jest też inny niż u mężczyzn. Kobiety krócej pozostają w szpitalu i są rzadziej hospitalizowane w porównaniu z mężczyznami [22]. Naukowcy oparli swoją koncepcję na dobroczynnym wpływie hormonów estrogenowych na zmniejszenie objawów psychotycznych oraz ich ochronnym działaniu w opóźnieniu początku choroby u kobiet $[29,30,31]$. Badania amerykańskie przeprowadzone w 2005 r. wykazały, że kobiety chore na schizofrenię $\mathrm{w}$ wielu przypadkach miały niższe wartości estrogenów niż kobiety zdrowe [32]. Stwierdzono także, że kobiety są bardziej narażone na zachorowanie lub nawrót choroby w okresie życia związanym ze spadkiem tych hormonów, czyli w okresie po urodzeniu dziecka oraz okresie okołomenopauzalnym [33]. Z danych statystycznych wynika, że kobiety ogółem, w okresie okołoporodowym wykazują większą częstotliwość występowania objawów zaburzeń psychicznych [34], ale objawy psychotyczne ujawniające się w okresie ciąży należą raczej do rzadkości [29]. Wśród czynników predysponujących do ich wystąpienia wymienia się: obecność objawów psychotycznych w poprzedniej ciąży, wcześniej występujące objawy psychotyczne, zaburzenia nastroju, występowanie objawów psychotycznych w trakcie ciąży u innych kobiet w rodzinie. [29]. Istnieje od 10\% do $15 \%$ ryzyka, że dzieci kobiet chorych na schizofrenię będą również na nią chorowały. Sprzyjają temu dodatkowe czynniki, takie jak: brak dostatecznej opieki rodzicielskiej, działanie leków w okresie prenatalnym oraz komplikacje położnicze [22]. Stwierdzono także, że dzieci matek z 
nadciśnieniem tętniczym w czasie ciąży oraz leczonych diuretykami $\mathrm{w}$ trzecim trymestrze, znajdowały się $\mathrm{w}$ grupie zwiększonego ryzyka rozwoju schizofrenii [35]. Należy też nadmienić, że diuretyki nie wykazują działania teratogennego, ale ich stosowanie w czasie ciąży nadal jest kontrowersyjne [35]. Funkcje rozrodcze w przebiegu schizofrenii nie są zaburzone [29, 36], ale przebieg choroby może doprowadzić do wycofania społecznego, trudności w budowaniu relacji bliskości z innymi osobami, budowania trwałych związków [36]. W trakcie choroby kobiety mogą negować istnienie ciąży, a przeżywanie psychozy może utrudniać jej rozpoznanie [22]. Chore psychicznie kobiety znacznie rzadziej korzystają z opieki lekarskiej w czasie ciąży $\mathrm{w}$ porównaniu z kobietami ze zdrowej populacji. Znacznie częściej w ich przypadku są to ciąże nieplanowane i niechciane. Dość często zdarza się również, że są one ofiarami przemocy w czasie ciąży [22]. Ciężarne chore psychicznie mogą też urojeniowo zaprzeczać istnieniu ciąży. Psychotyczne przeżycia mogą prowadzić do odrzucenia opieki lekarskiej, trudności w rozpoznaniu początków akcji porodowej oraz (rzadko) do zabójstw noworodków [22]. Kobiety chorujące na schizofrenię, będące w ciąży mogą prowadzić niezdrowy tryb życia przez: stosowanie niewłaściwej diety, używek (papierosów, alkoholu, narkotyków) oraz braku należytej opieki położniczej, działań profilaktycznych (stosowanie suplementacji kwasu foliowego) i kontrolnych badań laboratoryjnych (np. w kierunku anemii, cukrzycy ciężarnych) oraz badań ultrasonograficznych [37]. Duży procent osób chorych jest uzależnionych od nikotyny, według niektórych źródeł od $74 \%$ do nawet $92 \%$. Od nikotyny uzależnione są także kobietyinajczęściejnieprzerywająoneuzależnieniawokresie ciąży [22]. Okazało się, że kobiety chorujące na schizofrenię rzadziej uczestniczyły w wizytach ginekologicznych dotyczących opieki prenatalnej [25], co może mieć ogromne konsekwencje dla płodu. Kolejnym istotnym czynnikiem zagrażającym kobietom chorym na schizofrenię jest podwyższone ryzyko próby samobójczej [38]. Aktualnie w Polsce nie istnieją programy opieki nad ciężarną chorą psychicznie kobietą. Także w ramach programów rehabilitacyjnych dla osób chorych nie są przewidziane moduły psychoedukacyjne oraz treningi umiejętności dotyczące stosowania środków antykoncepcyjnych, zachowań seksualnych, opieki nad dzieckiem czy zakładania rodziny [22]. W 2011 r. przeprowadzono metaanalizę badań [39], w której wyszczególniono czynniki ryzyka wpływające na przebieg ciąży, porodu oraz powikłań dla dziecka i matki. Są to: palenie papierosów, starszy wiek pacjentki, dyskryminacja, nieplanowana ciąża, ekspozycja na leki w trackie ciąży, późne stwierdzenie ciąży, słabe przywiązanie kobiety do rozwijającego się płodu, niedostateczna opieka prenatalna oraz inne choroby współistniejące. Wiadomo też, że kobiety chorujące na schizofrenię przeżywają więcej stresu i lęku, w porównaniu do kobiet zdrowych, zwłaszcza jeśli chodzi o strach przed utratą dziecka [40].

\section{Przebieg porodu kobiet chorujących na schizofrenię}

Skurcze przepowiadające (występujące niekiedy na 2-3 tyg. przed porodem) wymagają różnicowania z właściwymi skurczami porodowymi $[9,41]$, gdyż mogą być błędnie interpretowane jako niespecyficzne dolegliwości bólowe jamy brzusznej. Około 75-85\% kobiet rodzi spontanicznie w ciągu doby od samoistnego odpłynięcia płynu owodniowego po 36 tygodniu ciąży [41] - aktualnie brak jest danych dotyczących tego odsetka u kobiet chorujących na schizofrenię. Preindukcja porodu (mechaniczne rozszerzenie kanału szyjki macicy z użyciem cewnika Foleya) poprzedza indukcję i zwiększa szansę na jej powodzenie [41], ale częstotliwość wykonywania tej procedury u kobiet chorujących na schizofrenię nie była dotychczas badana. Indukcja porodu zaś ma na celu doprowadzenie do porodu siłami natury przez stymulację czynności skurczowej macicy przed samoistnym rozpoczęciem się akcji porodowej [41, 42, 43]. Zgodnie $\mathrm{z}$ rekomendacjami PTG indukcja porodu uznawana jest za metodę leczenia w przypadkach, gdy korzyści wynikające z szybkiego ukończenia ciąży przewyższają ryzyko związane z jej kontynuacją i zawsze należy porównać korzyści z potencjalnym ryzykiem dla matki i płodu $[43,44]$. Z badań kohorty australijskiej, opublikowanych w 2016 r. wynika, że kobiety $(\mathrm{N}=222)$ z ciężkimi zaburzeniami psychicznymi, w tym psychozami, wielokrotnie częściej wymagały stosowania indukcji porodu, w porównaniu do kobiet z grupy kontrolnej $[45,46]$. Procedura indukowania porodu była stosowana u pacjentek chorujących na schizofrenię znacznie częściej z przyczyn położniczych niż psychiatrycznych (40\% vs 15\%) [45]. Najczęstszą metodą farmakologicznej indukcji porodu jest podawanie oksytocyny [41]. Obecny stan wiedzy dotyczący roli układu oksytocynergicznego i wahania stężenia oksytocyny stosowanej w celach indukcji porodu dla rozwoju objawów psychotycznych, nie pozwala w dostateczny sposób wyjaśnić wszystkich wątpliwości [46]. Zaleca się więc unikania stosowania preparatów $\mathrm{z}$ grupy ligandów receptora oksytocynowego u kobiet $\mathrm{z}$ rozpoznaniem zaburzeń psychotycznych $\mathrm{w}$ wywiadzie [47]. Wlew oksytocyny wiąże się z raptownym wzrostem, a następnie kaskadowym spadkiem stężenia tego hormonu [46]. Z chwilą rozpoczęcia się połogu następuje gwałtowny wzrost stężenia kortykoliberyny (CRF), estrogenów i progesteronu [46]. Jest to sytuacja, w której dochodzi do zwiększonego ryzyka rozwoju zaburzeń psychicznych 
[46]. Poród ze względów edukacyjnych i praktycznych został podzielony na IV fazy. W oparciu o rekomendacje PTG w pierwszym i drugim okresie porodu u kobiety z chorobami mogącymi negatywnie wpływać na stan dziecka i w przypadku wystąpienia nieprawidłowości w przebiegu porodu (ze względu na możliwość szybkiego wykonania zabiegu położniczego lub cięcia cesarskiego kończącego poród) w czasie porodu drogą natury niezbędna jest obecność lekarza [41]. Przedłużenie II okresu porodu może sprzyjać niedotlenieniu wewnątrzmacicznemu, urazom tkanek kanału rodnego $\mathrm{w}$ czasie porodu i zaburzeniu obkurczania się macicy po porodzie, a skrócenie przerw międzyskurczowych może doprowadzić do hipoksji płodu [41]. Stąd tak ważna jest współpraca pacjentki z położną lub położnikiem w czasie trwania tej fazy porodu. Rutynowo na tym etapie porodu zaleca się także ochronę krocza [41]. Obecnie brak jest danych dotyczących częstości wykonywania zabiegu episiotomii u kobiet chorujących na schizofrenię. W początkowym okresie łożyskowym rośnie stężenie metabolitów prostaglandyn PGF2 $\alpha$ i PGE2, które po części odpowiadają za skurcze poporodowe mięśnia macicy. Według aktualnie obowiązujących wytycznych w aktywnym prowadzeniu III okresu porodu zaleca się zastosowanie $\mathrm{w}$ profilaktyce leków naskurczowych oksytocyny (lek pierwszego rzutu), karbetocyny (działa skuteczniej, szybciej i dłużej niż oksytocyna w przypadkach subatonii lub atonii macicy) i alkaloidów sporyszu (rzadko stosowane ze względu na działania niepożądane) [41]. Bezpośrednio po porodzie (IV faza) ocenia się stan ogólny pacjentki (ciśnienie, tętno, temperaturę), stan obkurczenia macicy oraz ciągłość tkanek kanału rodnego [41]. Pacjentka powinna pozostawać $\mathrm{w}$ obrębie bloku porodowego, gdyż właśnie w tych pierwszych godzinach istnieje największe ryzyko krwotoku [41]. Należy uprzedzić pacjentkę o konieczności zgłaszania zwiększonego krwawienia z dróg rodnych [41]. Szczególnego nadzoru wydają się więc wymagać pacjentki chorujące na schizofrenię, które w przebiegu choroby nie będą współpracowały z personelem traktu porodowego. Ponadto brak współpracy może znacznie zwiększać ryzyko powikłań u dziecka.

\section{Powikłania położnicze kobiet chorujących na schizofrenię}

Powikłania okołoporodowe to wszystkie wydarzenia, które zakłócają prawidłowy przebieg porodu.

Wiele badań potwierdziło, że powikłania położnicze są częstsze u kobiet ze schizofrenią niż w populacji ogólnej [48 - 54]. Dotyczy to zarówno powikłań przebiegu ciąży jak i porodu $[24,55,56]$. Badania te potwierdzają też pośrednio przypuszczenie, że nieprzewidywalne zachowanie pacjentki będącej w psychozie w czasie porodu może wikłać jego przebieg [57]. Udowodniono też, że komplikacje okołoporodowe stanowią jeden z czynników warunkujących zwiększenie ryzyka zachorowania na schizofrenię $[55,58]$. Dodatkowo wykazano, że sama ciąża kobiet wcześniej leczonych z powodu psychozy niesie za sobą dwukrotnie zwiększone ryzyko powikłań ciąży i porodu, głównie w zakresie porodu przedwczesnego i niskiej masy urodzeniowej noworodka [59]. Badania potwierdziły także, że powikłania położnicze występują częściej u naturalnego rodzeństwa pacjentek chorujących na schizofrenię [48]. W cytowanych już badaniach Sacker'a i wsp. wykazano, że ryzyko komplikacji położniczych [obstetric complications (OCs)] w czasie porodu było wyższe, gdy chora na schizofrenię była matka, niż gdy chorował ojciec dziecka [57].

W 2002 r. przeprowadzono metaanalizę badań, w której potwierdzono, że ze schizofrenią znacząco związane są 3 rodzaje komplikacji porodowych:

1. komplikacje dotyczące samej ciąży: krwawienie, cukrzyca, niezgodność w zakresie czynnika Rh, stan przedrzucawkowy

2. nieprawidłowy wzrost wewnątrzpłodowy: niska masa urodzeniowa, wrodzone malformacje, zmniejszony obwód główki

3. komplikacje dotyczące rozwiązania ciąży: atonia macicy, asfiksja, nagłe cięcie cesarskie [60].

W badaniu 29 probantów opartym na McNeil-Sjostrom Scale (skali oceniającej powikłania położnicze) wykazano, że krwawienie w trakcie ciąży, przedłużający się poród, problemy z donoszeniem ciąży, zaburzenia oddychania u noworodków, poród z użyciem kleszczy, pilne cięcie cesarskie, odwrócona pozycja płodu, wczesny wiek ciążowy podczas porodu, ekstremalne wcześniactwo, niska masa urodzeniowa były najczęstszymi powikłaniami położniczymi stwierdzanymi u kobiet ze schizofrenią [61]. W innym badaniu australijskim stwierdzono większą częstotliwość występowania wad łożyska, krwotoków przedporodowych i w czasie porodu oraz niedotlenienia płodu [62].

\section{Komplikacje dotyczące przebiegu samej ciąży}

\section{Krwawienie}

Krwawienie w czasie ciąży może mieć wiele przyczyn. Krwawienie implantacyjne i skrócone miesiączki oraz poronienia są powszechne $\mathrm{w}$ pierwszym miesiącu ciąży [60]. Poronienia ze względu na stopień nasilenia objawów można podzielić na: poronienie zagrażające, w toku oraz poronienie zatrzymane, a ich przyczynę można wytłumaczyć po badaniu anatomicznym, hormonalnym, 
wykryciu zakażenia i zaburzeń metabolicznych, czynników genetycznych lub autoimmunologicznych [9,60]. Wśród innych przyczyn wymienia się urazy dróg rodnych, rozpoczynający się poród i współistniejący z ciążą nowotwór dróg rodnych [63], ciążę wielopłodową, nadciśnienie w przebiegu ciąży (stan przedrzucawkowy, rzucawka, HELLP), chorionamnionitis, wielowodzie, obumarcie płodu, niedokrwistość, wieloródkę >5 ciąż, mięśniaki macicy, krwotok w wywiadzie, otyłość (mniejsze znaczenie) [64]. U kobiet ze schizofrenią krwawienie z łożyska przodującego (22\% przyczyn krwawień) i przedwczesnego odklejenia się łożyska ( w przypadku prawidłowo usadowionego łożyska - 31\%) są częste w II i III trymestrze ciąży, zwłaszcza w ostatnim miesiącu [60]. Przyczyny krwawień w średnio zaawansowanej ciąży są znacznie mniej zrozumiane niż te występujące na jej początku lub końcu [60]. W jednym z badań 2/3 przypadków krwawień tego okresu ciąży wystąpiło w przebiegu przedwczesnego odklejenia się łożyska, łożyska przodującego, zaśniadu groniastego, niewydolności szyjki macicy albo innych zidentyfikowanych przyczyn, podczas gdy $1 / 3$ przypadków nie została do końca określona [65]. W nielicznych przypadkach krwawień przyczyną była patologia płodu z niedotlenieniem, ale w zdecydowanej większości objętość samego krwawienia była niewielka $[66,67]$.

\section{Stan przedrzucawkowy}

Stan przedrzucawkowy i rzucawka to zespół swoistych objawów chorobowych, które obserwuje się po 20 tygodniu ciąży, w okresie porodu lub połogu, charakteryzujący się podwyższonym ciśnieniem tętniczym krwi (ciążowy wzrost ciśnienia tętniczego $\geq 140 / 90 \mathrm{~mm} \mathrm{Hg}$ ), któremu towarzyszy znamienny białkomocz (utrata $\geq 300 \mathrm{mg}$ białka na dobę) [68]. Rzucawka charakteryzuje się występowaniem w stanie przedrzucawkowym drgawek toniczno-klonicznych połączonych z utratą przytomności, które nie mają innej przyczyny poza nadciśnieniem ciążowym [68, 69]. Może pojawić się małopłytkowość (liczba płytek <100 000/mm3) i wzrost aktywności enzymów wątrobowych [68], wzrost poziomu kreatyniny powyżej $1,2 \mathrm{mg} / \mathrm{dl}$ (w przypadkach gdy nie było wcześniej podwyższone), bóle głowy, nieostre widzenie, bóle $w$ nadbrzuszu, nudności i wymioty [69]. Szczególną uwagę zwrócono na stan przedrzucawkowy w 1996 r., kiedy to Kendell i wsp. potwierdzili bardzo duże powiązanie pomiędzy preeklampsjąi późniejszą schizofrenią $[60,70]$. Powtórna analiza nie potwierdziła aż tak znaczącej roli stanu przedrzucawkowego, ale późniejsze duże badanie populacyjne wykazało, że jest ona jedynym położniczym czynnikiem ryzyka wśród innych potencjalnych czynników rozwoju schizofrenii u dziecka [71]. Najbardziej popularna obecnie teoria łączy mechanizm zaburzonego przepływu krwi u płodu z przewlekłą hipoksją lub niedożywieniem [60], ale brane są także pod uwagę zmiany zapalne.
Przyszłościowe badania neuroobrazowe mogą dostarczyć istotnych informacji o wpływie stanu przedrzucawkowego na mózg płodu [72, 73].

\section{Niezgodność w zakresie czynnika Rh}

Mechanizmy autoimmunologiczne mogą mieć także wpływ na związek pomiędzy niezgodnościami w zakresie czynnika Rh i późniejszą schizofrenią [74, 75]. Choroba hemolityczna noworodków to zaburzenie neurologiczne, którego wtórne konsekwencje mogą doprowadzić do wczesnego, spontanicznego poronienia, przewlekłej hipoksji płodu, zamartwicy noworodka, obrzęku płuc, hiperbilirubinemii noworodków oraz kernicterus [74, 76]. Niezgodność w zakresie czynnika Rh jest przykładem, gdzie matczyne rozpoznanie i sensytyzacja na komórki płodu (RBC) prezentujące antygen, może doprowadzać do produkcji immunoglobulin w klasie G, które przechodząc przez łożysko doprowadzają do lizy krwinek czerwonych [51]. Okazało się, że niezgodność w zakresie czynnika Rh może prowadzić do niedotlenienia płodu i pośrednio wpływać na przebieg ciąży i porodu oraz powodować częstsze wystąpienie zaburzeń struktury mózgu u dzieci kobiet chorujących na schizofrenię [77].

\section{Cukrzyca ciężarnych}

Związek cukrzycy z ciążą i późniejszą schizofrenią, pomimo tego, ze bardzo silny, jest oparty jedynie na analizie kilku badań $[60,78,79]$. Pośrednio badanie przeprowadzone przez Schaefer i wsp. [78] potwierdza, że podwyższona masa ciała u ciężarnej podnosi ryzyko schizofrenii u potomstwa. Ponadto wykazano w tym badaniu, że słabo kontrolowana matczyna cukrzyca podwyższa ryzyko wystąpienia wad wrodzonych, upośledzenia intelektualnego oraz rozwoju psychoruchowego. Okazało się też, że cukrzyca insulinozależna jest częstsza wśród krewnych pierwszego stopnia pacjentów chorujących na schizofrenię w porównaniu do osób zdrowych, co może sugerować zaangażowanie czynników autoimmunologicznych [60, 80, 81]. Mechanizm, w którym cukrzyca ciężarnych miałaby zwiększać ryzyko wystąpienia schizofrenii, obejmuje interakcje między środowiskiem wewnątrzmacicznym wyzwalanym przez matczyną hiperglikemię a genetyczną podatnością płodu [78].

\section{Powikłania dotyczące nieprawidłowego wzrostu wewnątrzpłodowego}

\section{Niska masa urodzeniowa}

W wielu badaniach potwierdzono związek z niską masą urodzeniową a schizofrenią $[60,82,83]$. Ale związek ten nie jest do końca ugruntowany $[49,84,85,86]$, co głównie związane jest z dużą rozpiętością masy ciała dziecka 
branej pod uwagę w badaniach. Niska masa urodzeniowa najczęściej może być spowodowana wcześniactwem lub wewnątrzmacicznym zahamowaniem wzrostu [87]. Używając ilościowego podejścia Wahlbeck i wsp. odkryli, że ryzyko schizofrenii zmniejsza się w sposób liniowy wraz ze wzrostem masy ciała, wzrostem długości urodzeniowej ciała oraz wzrostem masy łożyska (prawidłowo ok 500g) [87]. Niska masa urodzeniowa oraz zmniejszona długość ciała podnosiła ryzyko rozwoju schizofrenii [87]. W metaanalizie badań przeprowadzonej w 2002r. wykazano, że ryzyko rozwoju schizofrenii jest raczej zależne od wewnątrzmacicznego zahamowana wzrostu [88]. Podobną sugestię wysnuto $\mathrm{w}$ innym badaniu, sugerując, że mała wielkość łożyska i późnociążowa niska masa ciała matki mogą mieć swoje odzwierciedlenie w niedożywieniu płodu [87]. Z powyższego zestawienia wiadomo także, że kobiety, które już chorują na schizofrenię lub zachorują później należą do grupy osób z ryzykownymi zachowaniami takimi jak palenie papierosów, używanie leków i słabego uczestnictwa w kontrolach położniczych, czyli czynników ryzyka, których konsekwencją może być niska masa urodzeniowa [60]. W wielokrotnie cytowanym badaniu przeprowadzonym po epidemii grypy w Finlandii udowodniono związek wzrostu zachorowań na schizofrenię u dzieci matek, będących w drugim trymetrze ciąży [89]. Dużo badań potwierdzało podobny wzrost zachorowań przy infekcji górnych dróg oddechowych, infekcji dróg rodnych, różyczki, Toxoplasma gondii, wirusa opryszczki typu 2 [89]. Ponadto niska masa urodzeniowa, stan przedrzucawkowy, zapotrzebowanie na inkubator po urodzeniu, konieczność użycia kleszczy podczas porodu, psychozy $\mathrm{w}$ rodzinie były związane $\mathrm{z}$ wcześniejszym wiekiem wystąpienia psychozy (age at onset of psychosis - AOP). Przy czym używanie kleszczy i masa urodzeniowa są zmiennymi, które najlepiej przewidują AOP w pierwszym epizodzie psychozy (first episode of psychosis - FEP). Leki pobudzające, które były najczęściej stosowane razem z marihuaną i kokainą, były jedynymi substancjami związanymi z wcześniejszym AOP [90]

\section{Malformacje wrodzone}

Zdecydowana większość wad wrodzonych, które były oceniane w metaanalizie z 2002 r. należą do niewielkich fizycznych nieprawidłowości (minor physical anomalies' - MPAs) [60, 91, 92]. W badaniu Thomasa i wsp. [93] potwierdzono większe występowanie zaburzeń struktury mózgu u dzieci kobiet chorujących na schizofrenię, które podczas porodu doświadczyły komplikacji położniczych, zwłaszczaprzedłużającegosięporoduorazurazówdoznanych w czasie ciąży i porodu. Niewielkie fizyczne nieprawidłowości stwierdzane były najczęściej w zakresie głowy: oczy, usta, uszy ale także dłoni, stóp i pozostałych części kończyn [94]. Zaburzenia budowy mózgu u tych dzieci dotyczyły przede wszystkim zmniejszenia lewego hipokampa, powiększenia lewej komory bocznej mózgu oraz komory trzeciej [93, 95]. Raportowano także poszerzenie bruzd i szczelin korowych, co mogło sugerować występowanie w tych obszarach obniżenia objętości dyfuzyjnej o łagodnym stopniu. Ponadto stwierdzano zmniejszenie płatów czołowych oraz mniejszej objętości istoty szarej w hipokampach oraz płatach skroniowych $[93,96,97]$.

\section{Zmniejszony obwód główki płodu}

Obwód główki noworodka jest powszechnie używanym pomiarem do orientacyjnej oceny stanu nowonarodzonego dziecka. Badanie obwodu główki dziecka (obwód czołowopotyliczny) przeprowadza się taśmą krawiecką przez największą wypukłość potyliczną i największą wypukłość guzów czołowych [98]. U zdrowego, dojrzałego noworodka płci męskiej wynosi on $35 \mathrm{~cm}$ (3-97 percentyl: $33-37 \mathrm{~cm})$, jest on większy o 1-2 cm od obwodu klatki piersiowej. U dziewczynek wynosi on 1-2 cm mniej. Za zmniejszony obwód główki uważa się wartości poniżej podanych norm. Wykazano też, że zmniejszona masa urodzeniowa oraz mały obwód główki (mniej niż 31,5 cm) były powiązane z późniejszym rozwojem schizofrenii [99].

\section{Komplikacje dotyczące rozwiązania ciąży}

Mechanizmy, które doprowadzają do wystąpienia trudności w donoszeniu ciąży powodowały też większe ryzyko wystąpienia u płodu stanu hipoksji lub anoksji [60]. Trudno jednak zmierzyć poziom niedotlenienia, stąd wiele badań opartych było na różnorodnych definicjach tych stanów [60]. U osób z trzema lub więcej powikłaniami położniczymi przebiegającymi z hipoksją, 5 razy częściej występowała schizofrenia w porównaniu do osób bez takich powikłań [100]. Autorzy tych badań $[100,101]$ sugerują, że uzyskane przez nich rezultaty są spójne z modelem rozwoju schizofrenii łączącej podatność genetyczną z komplikacjami położniczymi oraz że skutki neurotoksyczne niedotlenienia płodu mogą prowadzić do wcześniejszego rozwoju schizofrenii. Przypuszczalnie komplikacje przebiegające $\mathrm{z}$ hipoksją mogą być powiązane z nieprawidłowościami w zakresie struktury mózgu u pacjentów ze schizofrenią [102].

\section{Nagłe cięcie cesarskie i poród przedwczesny}

Wskazania do zakończenia ciąży mogą wystąpić zarówno w ciąży o prawidłowym jak i patologicznym przebiegu ze względów matczynych i/lub płodowych [41]. Zagrożenie porodem przedwczesnym, jak również porodem po terminie, $\mathrm{z}$ psychologicznego punktu widzenia prowadzi do powstania niezwykle silnego stresu. Najbardziej dominującą emocją jest tu oczywiście lęk [37]. Według obecnie obowiązującego stanowiska Polskiego Towarzystwa Ginekologicznego cięcie cesarskie (cc) jest 
to operacja położnicza, mająca na celu ukończenie ciąży lub porodu, gdy dalsze oczekiwanie na ich naturalne zakończenie przedstawia niebezpieczeństwo dla matki i dziecka [103]. W przytoczonych Rekomendacjach (powołując się na opracowanie Słomki i wsp) wskazania do cięcia cesarskiego podzielono na 4 grupy w zależności od stopnia pilności operacji: wskazania elektywne (planowe), pilne, naglące i nagłe [104]. Wśród wskazań elektywnych do wykonania cięcia cesarskiego znalazły się też przyczyny pozapołożnicze: kardiologiczne, okulistyczne [105], ortopedyczne, neurologiczne oraz psychiatryczne [103]. Te ostatnie według autorów są najbardziej kontrowersyjnymi i rzadkimi wskazaniami pozapołożniczymi [103]. Najczęściej dotyczą braku akceptacji porodu siłami natury i nastawienia lękowego do porodu [103]. Ginekolodzy podkreślają, że wiele tego typu wskazań należy traktować krytycznie oraz rozważać je jako wskazania czasowe, które mogą podlegać weryfikacji w czasie skutecznej psychoterapii i farmakoterapii oraz nabywania wiedzy o porodzie w szkole rodzenia [103]. Pomimo budzących kontrowersji wskazania psychiatryczne do rozwiązania porodu drogą cięcia cesarskiego nie zostały dokładnie omówione [46]. Nie uwzględniono także, które spośród zaburzeń psychicznych mogą stanowić bezwzględne lub względne wskazanie do cięcia cesarskiego [46]. Według danych $\mathrm{z}$ polskiego piśmiennictwa psychiatrycznego i ginekologicznego dotychczas nie udało się sprecyzować zakresu zaburzeń psychiatrycznych, których występowanie u kobiety ciężarnej mogłoby skutkować rozwiązaniem porodu drogą cięcia cesarskiego i w każdym przypadku psychiatryczne wskazania do wykonania cięcia cesarskiego powinny być rozpatrywane indywidualnie [46]. Decydującym kryterium powinna być potencjalna współpraca pacjentki z personelem położniczym w trakcie porodu siłami natury [46]. Aktualnie brak jest danych o ilości porodów przeprowadzonych w Polsce u pacjentek z dodatnim wywiadem w kierunku chorób psychicznych. Brak jest także statystyk dotyczących form zakończenia ciąży u takich pacjentek [46]. Na podstawie danych literaturowych można wyróżnić dwa rodzaje wskazań psychiatrycznych do rozwiązania ciąży drogą cięcia cesarskiego [46]. Pierwsza grupa wskazań dotyczy pacjentek z dodatnim wywiadem w kierunku zaburzeń psychiatrycznych lub obserwacji zmienionego $\mathrm{w}$ przebiegu choroby psychicznej zachowania ciężarnej w czasie trwania całej ciąży lub w okresie bezpośrednio poprzedzającym poród [46]. Niedostosowane zachowanie takich pacjentek może budzić wiele wątpliwości wśród położników dotyczących współpracy podczas akcji porodowej i oczywistym wydaje się uwarunkowanie poziomu współpracy z nasileniem zaburzeń psychicznych [46]. Poród przez cięcie cesarskie może spowodować poprawę kontroli przebiegu porodu i przez to zapobiegać rozwojowi powikłań okołoporodowych wynikających $\mathrm{z}$ wydłużenia kolejnych faz porodu podczas nieumiejętnej współpracy rodzącej lub nagłego zaostrzenia zaburzeń psychicznych w okresie okołoporodowym [46]. Druga grupa wskazań dotyczy nasilonego lęku przed porodem (tokofobii) [46]. W literaturze nie scharakteryzowano dotychczas postaci tokofobii, które mogą być skutecznie zredukowane przez psychoedukację lub interwencje psychoterapeutyczne [46]. W 2013 r. opublikowano w Wielkiej Brytanii wytyczne National Institute of Health and Care Excellence (NICE) dotyczące charakteru tokofobii, która miałaby być wskazaniem do rozwiązania porodu drogą cięcia cesarskiego [106]. Według wyżej wymienionych standardów każda kobieta ciężarna, która zgłasza objawy lęku przed porodem powinna zostać skonsultowana przez specjalistę z zakresu zdrowia psychicznego, ciąży i połogu. Przed konsultacją powinna mieć możliwość omówienia wszystkich wskazań medycznych dotyczących rozwiązania ciąży obiema metodami [106]. Jeśli po odbyciu cyklu spotkań psychoedukacyjnych pacjentka $\mathrm{z}$ objawami lęku przed porodem, nadal nie wyraża zgody na poród siłami natury, to według wytycznych NICE ciąża powinna zostać ukończona przez cięcie cesarskie $[106,107]$. W Polsce w tym celu wykorzystuje się programy psychoedukacyjne stosowane w szkołach rodzenia [106]. W dostępnej literaturze polskiej brak jest danych na temat preferowanych sposobów ukończenia ciąży u kobiet $\mathrm{z}$ poważnymi zaburzeniami psychicznymi (w tym schizofrenią czy chorobą afektywną dwubiegunową) [46].

\section{Łożysko przodujące i przedwczesne oddzielenie się łożyska prawidłowo usadowionego}

Wwieludoniesieniach potwierdzono związek pomiędzy komplikacjami położniczymi a schizofrenią [108], ale dopiero od kilku lat szczególną uwagę poświęcono patologii łożyska, wiążąc ją z wewnątrzpłodowym uszkodzeniem mózgu [109] i porażeniem mózgowym [110]. Łożysko produkuje wiele ważnych dla rozwijającego się mózgu substancji, takich jak serotonina [111] czy inne monoaminy, [63], wazoaktywny peptyd jelitowy [102]. Powikłania psychiatryczne mogą być ujawnione dopiero lata później [109], dotychczas zostało to udowodnione w przypadku zwiększonego ryzyka wystąpienia porażenia mózgowego [94]. Badania na zwierzętach wykazały nawet większą rolę łożyska we wspieraniu rozwijającego się mózgu płodu, gdy ze strony matki wystąpią zaburzenia odżywiania oraz $\mathrm{w}$ przypadku stresu, który mógłby poprzez zaprogramowaną ekspresję genów powodować wzrost katabolizmu łożyska doprowadzając „paliwo” dla mózgu płodu [112]. Łożysko 
standardowo badane jest histopatologicznie jedynie, gdy stwierdzono chorobę u dziecka podczas porodu [41, 113]. W jednym z badań potwierdzono, że łożysko przodujące i przedwczesne odklejenie się łożyska prawidłowo umiejscowionego są częstszą przyczyną powikłań położniczych u kobiet chorych na schizofrenię [39], w innym badaniu nie potwierdzono aż tak dużego wpływu pomiędzy grupą kontrolną (odpowiednio 1\% versus 4\%, p=0.333 i $1 \%$ versus $0.7 \%, \mathrm{p}=0.51$ ) [114]

\section{Inne powikłania}

Inne powikłania dotyczące ciąży kobiet ze schizofrenią nie zostały dotychczas skrupulatnie badane. Dotyczy to przede wszystkim: pęknięcia macicy, wstrząsu septycznego w przebiegu poronienia septycznego, pęknięcia pęcherza płodowego, wypadnięcia pępowiny, przetoki pęcherzowopochwowej, pęknięcia szyjki macicy, uszkodzenia sromu, uszkodzenia spojenia łonowego i kości guzicznej oraz krwiaka sromu, krocza i pochwy.

\section{Wnioski}

Ciężarne chorujące na schizofrenię to specyficzna grupa pacjentek. Opieka nad nimi w trakcie ciąży wymaga holistycznego podejścia. Powszechnie wiadomo, że ryzyko powikłań okołoporodowych jest wśród nich znacznie większe niż w populacji ogólnej. Przedstawiona analiza na pewno nie wyczerpała możliwych dylematów i problemów, które może napotkać personel medyczny. Jednak zdecydowanie może rozwinąć nić porozumienia miedzy psychiatrą i ginekologiem. Trudności jakie mogą wystąpić podczas leczenie tej specyficznej grupy pacjentek nadal będzie stanowić nie lada wyzwanie terapeutyczne dla lekarzy i pielęgniarek [88].

\section{Conflict of interest}

The authors have declared no conflict of interest.

\section{References}

1. Bączyk G., Cebulska V., Koźlak V., Michalak M., Bajek A., Marcinkowski JT. Poziom lęku przedporodowego u kobiet w ciąży. Probl. Hig Epidemiol. 2011; 92: 774-777.

2. Fórmaniak J., Kotzbach R., Jaroch A. Analiza wpływu sposobu ukończenia ciąży na stan psychiczny pacjentek. Perinatol Neonatol Ginekol. 2008; 1: 134-137.

3. McGrath JJ., Myths and plain truths about schizophrenia epidemiology - the NAPE lecture 2004. Acta Psychiatr Scand 2005; 111: 4-11

4. Mueser KT., McGurk SR., Schizophrenia. The Lancet, 94262004,
2063-2072.

5. Lichodziejewska-Niemierko M., Kicińska A., Rutkowski B. Wpływ ciąży na funkcję i strukturę nerek. Forum Nefrol.2009; 2:250-253.

6. Fraś M, Gniadek A, Poznańska-Skrzypiec J, Kadłubowska M. Styl życia kobiet w ciąży. Hygeia Public Health. 2012; 47: 412-417.

7. Conrad KP, Mechanisms of renal vasodilation and hyperfiltration during pregnancy. J Soc Gynecol Invest 2004; 11:438-448.

8. Wykrętowicz M Sztywność naczyń i zjawisko odbicia fali tętna u kobiet w ciąży. Praca na stopień doktora medycyny. 2010.

9. Bręborowicz GH. Położnictwo i ginekologia. Warszawa; wyd. PZWL: 2006.

10. Puchalska-Krotki H, Marcinowska-Suchowierska E Nabyte wady serca u kobiet w ciąży. Post Nauk Med 2010; 5: 408-412.

11. Sonya $S, A b$ Del-Razeq, Stany nagłe w położnictwie: niewydolność oddechowa, Ginekol Dypl. 2012; 1: 22-27.

12. Chmielewska-Szewczyk D, Ciąża u kobiety z astmą i jej wpływ na dziecko, Alerg Astma Immun 2013; 18: 145-150.

13. Bilińska M, Sokalski J, Pregnancy gingivitis and tumor gravidarum. Ginekol Pol 2016; 87:310-313.

14. Stukan M, Kruszewski WJ, Dudziak M, Kopiejć A, Preis K Niedrożność przewodu pokarmowego u kobiet ciężarnych. Ginekol Pol. 2013; 84:137-141.

15. Artal R, O'Toole M, White S, Guidelines of the American College of Obstetricians and Gynecologists for exercise during pregnancy and the postpartum period. Brit J Sports Med, 2003; 37: 6-12.

16. Uznanska A, Bezpieczna aktywność fizyczna kobiet w ciąży. Aktywność ruchowa ludzi w różnym wieku 2015; 3: 47-52.

17. August P, Podymow T The kidney in pregnancy. W: Greenberg A. red. Primer on kidney diseases. wyd.3 New York, Academic Press, 2009; 404-412.

18. Markwitz W, Oko A, Choroby nerek, W. Bręborowicz GH. red. Ciąża Wysokiego ryzyka. 2006; 719-728.

19. Milewicz T, Pulka M, Stochmal E, Pach D, Galicka- Latała D, Juszczyk L et al. Czynność endokrynna łożyska a oś podwzgórzowoprzysadkowo-tarczycowa u płodu. Prz Lek 2011; 68: 329-333.

20. Marek B, Krysiak R, Okopień B, Choroby nadnerczy w ciąży. Endokrynol Pol. 2009; 60: 331-342.

21. Godala M, Pietrzak K, Łaszek M, Gawron-Skarbek A, Szatko F, Zachowania zdrowotne łódzkich kobiet w ciąży. Cz. I. Sposób żywienia i suplementacja witaminowo-mineralna. Probl Hig Epidemiol. 2012; 93: 38-42.

22. Kasperek-Zimowska B, Brodniak WA, Sarol-Kulka A, Zaburzenia seksualne w schizofrenii - przegląd badań, Psychiatr Pol. 2008; XLII:97-105.

23. http://stat.gov.pl [strona domowa w Internecie].

24. Haukka J, Suvisaari J, Lömqvist J. Fertility of patients with schizophrenia; their siblings and the general population: A cohort study from 1950 to 1959 in Finland. Am J. Psychiatry 2003; 160: 460-463.

25. Bennedsen BE, Mortensen PB, Olesen AV, Henriksen TB, Frydenberg M, Obstetric complications in women with schizophrenia. Schizophr Res. 2001; 47: 167-175.

26. Castle DJ, Mc Garth J, Kulakarni J. Women and schizophrenia: an epidemiological perspective. New York; wyd. Cambridge University Press: 2000.

27. Takahashi S, Matsuura M, Tanabe E, Yara K, Nonaka K, Fukura Y et al. Age at onset of schizophrenia: Gender differences and influence of temporal socioeconomic change. Psychiatry Clin Neurosci 2001; 52:153-6.

28. Jaracz K, Górna K, Kiejda J, Rybakowski J, Prospektywna ocena wczesnego przebiegu schizofrenii u kobiet i mężczyzn po pierwszej 
hospitalizacji psychiatrycznej Psychiatr Pol. 2008; XLII:33-46.

29. Barasińska- Tarka E., Kłoszewska I., Przyczyny gorszych wyników położniczych u kobiet chorujących na schizofrenię, Psychiatr. Psychol. Klin. 2011; 11: 206-213.

30. Dudzik D, Wójciak P, Rybakowski J Zaburzenia neuroendokrynne w pierwszym epizodzie psychozy, Farmakoterapia w Psychiatrii i Neurologii. 2012; 3-4, 135-142.

31. Kulkarni J, Hayes E, Gavrlidis E. Hormones and schizophrenia. Curr Opinion Psychiatry 2012;25:89-95.

32. Vedder H, Behl C, Estrogens in neuropsychiatric disorders. From physiology to pathophysiology. W: Bergmann N., Riecher- Rössler A. red.: Estrogen Effects in Psychiatric Disorders, Wien, New York: wyd. Springer, 2005:1-30.

33. Riecher-Rössler A, Seeman MW. Oestrogens and schizophrenia -introduction. Arch.Women Ment Health. 2002;5:91-92.

34. Watkins ME, Newport DJ, Psychosis in pregnancy. Obstet. Gynecol. 2009; 113: 1349-1353.

35. Sorensen HJ, Mortesnen EL, Reinisch JM, Mednick SA, Do Hypertension and Diuretic Treatment in Pregnancy Increase the Risk of Schizophrenia in Offspring? 2003;160:464-468.

36. Motezedian S, Babakhani L, Fereshtchncjad SM, Mortality outcome of hiperprolactinemia infertile women undergoing intrauterine insemination Indian J Med Res. 2010; 131:670-674.

37. Kwaśniewska A, Kraczkowski J, Wartacz E, Robak J, Semczuk M, Ocena lęku oraz analiza struktury osobowości kobiet zagrożonych porodem przedwczesnym oraz porodem po terminie. Post Psychiatr Neurol. 1996; 5:185-193.

38. Oates $\mathrm{M}$, Suicide: the leading cause of mental death. , Br J Psychiatry 2003; 183:279-281.

39. Matevosyan NR, Pregnancy and postpartum specifics in women ith schizofrenia: a meta-study. Arch. Gynecol. Obstet. 2011; 283:141147.

40. Jungbauer J, Stelling K, Kuhn J, Lenz A, How mothers and fathers suffering from schizophrenia expieriece their parenthood? Results from an in-depth interview study. Psychiatr. Prax. 2010; 37: 233239.

41. Rekomendacje zespołu ekspertów Polskiego Towarzystwa Ginekologicznego dotyczące opieki okołoporodowej i prowadzenia porodu. Ginekol. Pol. 2009;80: 548-557.

42. Oleszczuk J, Leszczyńska-Gorzelak B, Poniedziałek-Czajkowska E. Rekomendacje postępowania w najczęstszych powikłaniach ciąży i porodu. Lublin; wyd. BiFolium: 2002.

43. Indukcja porodu. Wytyczne postępowania klinicznego dla lekarzy położników, ACOG Practice Bulletin 2009. Ginekol Dypl 2010; 3:71-80.

44. Caughey AB, Sundaram V, Kaimal AJ, Cheng YW, Gienger A, Little SE et al. Maternal and neonatal outcome of elective induction of labor. Evid Rep Technol Assess. 2009; 176: 1-257.

45. Frayne J, Lewis L, Allen S, Hauck Y, Nguyen T. Severe mental illness and induction of laubour: autcomes for women a specialist antenatal clinic in Western Australia. Aust N Z J Obstet Gynaecol. 2014; 54:132-7.

46. Holka-Pokorska J, Jarema M, Stefanowicz A, Piróg- Balcerzak A, Wichniak A, Elektywne cięcie cesarskie ze wskazań psychiatrycznych, opis dwóch przypadków oraz rekomendacje kliniczne, Psychiatr. Pol. 2016: 50: 357-373.

47. Kulkarni J, Fitzgerald P, Bailey M. Estrogen in severe mental illness. A potential new treatment approach. Arch. Gen. Psychiatry 2008; 65: 955-960.

48. Walshe M, McDonald C, Preti A, Cardascia L, Zen T, Marchetti M et al. Obstetric complications in patients with schizophrenia and their unaffected siblings. Risk for obstetric complications and schizophrenia. Psychiatr Res 2000; 96: 127-139.

49. Dalman C, Thomas HV, David AS, Gentz J, Lewis G, Allebeck P. Signs of asphyxia at birth and risk of schizophrenia: population-based case-control study. Br J Pschiatry 2001; 179: 403-408.

50. Claarke MC, Harley M, Cannon M. The Role of Obstetric Events in Schizophrenia, Schizophrenia Bull. 2006; 32: 3-8.

51. Palmer CGS, Hsieh H-J, Reed EF, Longqvist J, Peltonen L, Woodward JA, Sinsheimer JS. HLA-B Maternal-Fetal Genotype Matching Increases Risk of Schizophrenia. Am J Hum Genet. 2006; 79:710715.

52. Boog G. Obstetrical complications and further schizophrenia of the offspring: a new reason for litigation? J Gynecol Obst Bio R. 2003; 32:720-727

53. Kandhal P, Miller BJ, Shared early life risk factors for schizophrenia and diabetes. Psychiatry and Health Behavior. Minerva Psichiatrica. 2013; 54:197-210.

54. Walshe M, McDonald C, Boydell J, Zhao JH, Kravariti E, Touloupoulou $\mathrm{T}$ et al. Long-term maternal recall of obstetric complications in schizophrenia research. Psychiat Res. 2011;187: 335-340.

55. Suvisaari JM, Taxel- Lassas V, Pankakoski M, Haukka JK, Lonnquist JK, Hakkinen LT. Obstetric complications as risk factors for schizophrenia spectrum psychoses in off-spring of mothers with psychotic disorder. Schizophr. Bull. 2013; 39: 1056-1066.

56. Schneid- Kofman N, Sheiner E, Levy A, Psychiatric illness and adverse pregnancy outcome. Int J Gynaecol Obstet. 2008; 101:53-6

57. Sacker A, Done D, Crow. T, Obstetric complications in children born to parents with schizophrenia: A met-ananlysis of case-control studies. Psychol Med 1996; 26: 279-287.

58. Boksa P., Animal models of obstetric complications in relation to schizophrenia, Brain Res Rev. 2004; 45: 1-17.

59. Nilsson E, Lichtenstein P, Cnattingius S, Murray RM, Hultman CM, Women with schizophrenia: pregnancy outcome and infant death among their offspring. Schizphr. Res. 2002; 58: 221-229.

60. Cannon M, Jones PB, Murray RM. Obstetric Complications and Schizophrenia: Historical and Meta-Analytic Review. Am J Psychiatry. 2002; 159:1080-92.

61. Nicodemus KK, Marenco S, Batten AJ, Vakkalanka R, Egan MF, Straub $\mathrm{RE}$ et al. Serious obstetric complications interact with hypoxiaregulated/vascular-expression genes to influence schizophrenia risk. Mol Psychiatry. 2008; 13: 873-877.

62. Jablensky V, Morgan V, Soc M, Zubrick SR, Bower C, Yellachich L. Pregnancy, Delivery, and Neonatal Complications in a Population Cohort of Women With Schizophrenia and Major Affective Disorders. Assen, Am J Psychiatry. 2005; 162: 79-91.

63. McKay R. Developmental biology: remarkable role for the placenta. Nature. 2011; 472: 298-299.

64. Sobieszczyk S, Bręborowicz GH, Rekomendacje postępowania w krwotokach poporodowych Część I. Protokół postępowania. Klin Perinatol Ginekol. 2004; 40: 60-63.

65. Scott JR: Vaginal bleeding in the midtrimester of pregnancy. Am J Obstet Gynecol. 1972; 113:329-334.

66. Torrey EF, Hersch SP, McCabe KD. Early childhood psychosis and bleeding during pregnancy. J Autism Child Schizophr. 1975; 5:2879.

67. Rieder RO, Broman SH, Rosenthal D. The offspring of schizophrenics, II: perinatal factors and IQ. Arch Gen Psychiatry. 1977; 34:789-799.

68. Saczko Z, Saczko J, Kulbacka J, Chwiłkowska A, Żórawski K. Nadciśnienie tętnicze u kobiet w ciąży. Etiopatogeneza. Nadciśn tętn. 2009; 13:199-205.

69. Szczepaniak-Chicheł L, Bręborowicz G, Tykarski A. Leczenie nadciśnienia tętniczego u kobiet w ciąży Nadciśn tętn. 2006; 10:83-98. 
70. Kendell RE, Juszcack E, Cole SK, Obstetric complications and schizophrenia: a case-control study based on standardised obstetric records. Brit J Psychiatry. 1996; 168: 556-56.

71. Sullivan PKF, Kendler KS, Neagle MC, Schizophrenia as a Complex Trait Evidence From a Meta-analysis of Twin Studies. Arch Gen Psychiatry. 2003; 60:1187-119.

72. Mak LE, Croy BA, Kay V, Reynolds JN, Rätsep MTB, Forket ND et al, Resting-state functional connectivity in children born from gestations complicated by preeclampsia: A pilot study cohort. Pregnancy Hypertens. 2018; 12: 23-28.

73. Pabalan N, Jarjanazi H, Sun C, Iversen AC, Meta-analysis of the human leukocyte antigen-G (HLA-G) 14 bp insertion/deletion polymorphism as a risk factor for preeclampsia Tissue Antigens. 2015; 86:186-94.

74. Hollister JM, Brown AS. Rhesus incompatibility and schizophrenia in Prenatal Exposures in Schizophrenia. W: Susser ES, Brown AS, Gorman JM. Red., American Psychiatric Press. Washington. 1999:197-214.

75. Palmer CGS, Mallery E, Turunen JA, Hsieh H-J, Peltonen L, Lonnqvist $\mathrm{J}$ et al. Effect of Rhesus D incompatibility on schizophrenia depends on offspring sex. Schizophr. Res. 2008;104:135-145.

76. Hollister JM, Kohler C. Schizophrenia: a long-term complication of haemolytic disease of the fetus and newborn? Int J Ment Health. 2001; 29:38-61.

77. Palmer CG, Turunen JA, Sinsheimer JS, Minassian S, Paunio T, Lönnqvist J et al. RHD maternal-fetal genotype incompatibility increases schizophrenia susceptibility. Am J Hum Genet. 2002; 71: 1312-1319.

78. Van Lieshout R, Voruganti L. Diabetes mellitus during pregnancy and increased risk of schizophrenia in offspring: a review of evidence and putative mechanisms. J Psychiatry Neurosci. 2008, 5, 395-404.

79. Nguyeen NT, Gorman M, Caughey AB. Pregnancy outcomes in women with schizophrenia: a retrospective cohort study, Am J Obstet Gynecol. 2016; 214: 296.

80. Wright P, Sham PC, Gilvarry CM, Jones PB, Cannon M, Sharma T et al. Autoimmune diseases in the pedigrees of schizophrenic and control subjects. Schizophr Res. 1996; 20:261-267.

81. Gilvarry CM, Sham PC, Jones PB, Cannon M, Wright P, Lewis SW et al. Family history of autoimmune diseases in psychosis. Schizophr Res 1996; 19:33-40.

82. Willinger U, Heiden AM, Meszaros K, Formann AK, Aschauer HN. Neurodevelopmental schizophrenia: obstetric complications, birth weight, premorbid social withdrawal and learningndisabilities. Neuropsychobiology. 2001;43:163-169.

83. Sørensen HJ, Mortensen EL, Reinisch JM, Mednick SA. Height, weight and body mass index in early adulthood and risk of schizophrenia. Acta Psychiat Scand, 2006; 114:49-54.

84. Kendell RE, McInneny K, Jusczak E, Bain M: Obstetric complications and schizophrenia: two case-control studies based on structured obstetric records. Br J Psychiatry. 2000; 174:516-522.

85. Byrne M, Browne R, Mulryan N, Scully A, Morris M, Kinsella A et al. Labour and delivery complications and schizophrenia: casecontrol study using contemporaneous labour ward records. Br J Psychiatry. 2000; 176:531-536.

86. Ichiki M, Kunugi H, Takei N, Murray RM, Baba H, Arai H et al. Intrauterine physical growth in schizophrenia: evidence confirming excess of premature birth. Psychol Med. 2000; 30:597-604.

87. Wahlbeck K, Forsen T, Osmond C, Barker DJP, Eriksson JG. Association of schizophrenia with low maternal body mass index, small size at birth and thinness during childhood. Arch Gen Psychiatry. 2001; 58:48-52.
88. Kmieciak B. Dylematy etyczno- prawne związane z hospitalizacją psychiatryczną kobiet w ciąży. Psychiatr. Psychol. Klin. 2011; 11:243-249.

89. Mittal VA, Ellman LN, Cannon TD. Gene-Environment Interaction and Covariation in Schizophrenia: The Role of Obstetric Complications Schizophrenia Bull. 2008; 34:1083-1094.

90. Rubio-Abadal E, Ochoa S, Barajas A, Baños I, Dolz M, Sanchez B et al. Birth, weight and obstetric complications determine age at onset in first episode of psychosis. J Psychiat Res. 2015; 65: 108-114.

91. McNeil T, Cantor-Graae E, Ishmail B. Obstetric complications and congenital malformations in schizophrenia. Brain Res Brain Res Rev. 2000; 31:166-178.

92. McNeil TF, Cantor- Graae E. Minor Physical Anomalies and Obstetric Complications in Schizophrenia. Austr NZ J Psychiat. 2000; 34 Suppl: 65-73.

93. McNeil TF, Cantor-Graae E. Weinberger DR: Relationship of obstetric complications and differences in size of brain structures in monozygotic twin pairs discordant for schizophrenia. Am J Psychiatry. 2000; 157:203-212.

94. Nielsen LF, Schendel D, Grove J, Hvidtjorn D, Jacobsson B, Josiassen $\mathrm{T}$ et al. Asphyxia-related risk factors and their timing in spastic cerebral palsy. BJOG 2008; 115: 1518-1528.

95. Haukvik UK, Saetre P, McNeil T, Bjerkan PS. An exploratory model for. G x E interaction on hippocampal volume in schizophrenia; obstetric complications and hypoxia- related genes. Prog NeuroPsychoph. 2010; 34: 1259-1265.

96. Falkai P, Schneider- Axmann T, Honer WG, Vogeley K, Schönell H, Pfeiffer $U$ et al. Influence of genetic loading, obstetric complications and premorbid adjustment on brain morphology in schizophrenia: A MRI study. Eur Arch Psychiatry Clin Neurosci. 2003, 253: 92-99.

97. Ebenr F, Tepest R, Dani I, Pfeiffer U, Schulze TG, Rietschel M et al. The hippocampus in families with schizophrenia in relation to obstetric complications. Schizophr Res. 2008; 104: 71-78.

98. Obuchowicz A, Badanie podmiotowe i przedmiotowe w pediatrii, 2016, wyd. 2 wyd. PZWL. Warszawa: 2016.

99. Nilsson E, Stålberg G, Lichtenstein P, Cbattingius S, Fetal Growth Restriction and Schizophrenia: A Swedish Twin Study. Twin Res Hum Genet. 2005; 4:402-408.

100. Cannon TD, Rosso IM, Hollister JM, Bearden CE, Sanchez, Hadley T. A prospective cohort study of genetic and perinatal influences in the etiology of schizophrenia. Schizophr Bull. 2000; 26:249-256.

101. Rosso IM, Cannon TD, Huttunen T, Huttunen MO, Lönnqvist J, Gasperoni TL. Obstetric risk factors for early-onset schizophrenia in a Finnish birth cohort. Am J Psychiatry 2000. 157:801-80.

102. Passemard S, Sokolowska P, Schwendimann L, Gressens P. VIPinduced neuroprotection of the developing brain. Curr Pharm Des. 2011; 17: 1036-1039.

103. Poręba R, Brazert J, Chazan B, Czajkowski K, Dębski R, Drews K et al. Rekomendacje Polskiego Towarzystwa Ginekologicznego. Cięcie cesarskie. Ginekol. Pol. 2008; 79: 378-384.

104. Słomko Z, Poręba R, Drews K, Niemiec K. Najważniejsze zagadnienia dotyczące cięcia cesarskiego. Ginekol. Położ. 2006: 2: 7-22.

105. Romaniuk W et al. Wskazania okulistyczne do cięcia cesarskiego. Wykład: Schorzenia okulistyczne a sposób rozwiązania ciąży. Perinatol Neonatol Ginekol. 2006.

106. https://www.nice.org.uk/guidance/qs32/chapter/introductionand-overview [strona domowa w Internecie] National Institute of Health and Care Excellence. NICE Quality Standard [QS 32].

107. Subair S, Osbourne A, Wilson S. Maternal Request Ceasarean Section: 2 NICE Pathways? Arch. Dis. Child. Fetal Neonatal Ed. 2014; 99 [supl.1].

108. Rapoport JL, Addington AM, Frangou S, Psych MR. The 
neurodevelopmental model of schizophrenia: update 2005. Mol Psychiatry. 2005; 10: 434-449.

109. Nelson KB, Blair E. The placenta and neurologic and psychiatric outcomes in the child: study design matters. Placenta 2011; 32: 623-625.

110. Blair E, de Groot J, Nelson KB. Placental infarction identified by macroscopic examination and risk of cerebral palsy in infants at 35 weeks of gestational age and over. Am J Obstet Gynecol 2011; 205: 124.e1-7.

111. Bonnin A, Goeden N, Chen K, Wilson ML, King J, Shih JC et al. A transient placental source of serotonin for the fetal forebrain. Nature 2011; 472: 347-350.

112. Zeltser LM, Leibel RL. Roles of the placenta in fetal brain development. Proc Natl Acad Sci 2011; 108: 15667-15668.

113. Rapoport JL, Giedd JN, Gotgay N, Neurodevelopmental model of schizophrenia: update 2012, Mol Psychiatry 2012;17;1228-1238.
114. Hizkiyahu R, A. Levy A, Sheiner E, Pregnancy Outcome of Patients with Schizophrenia, Amer. J. Of Perinatol. 2010; 27: 019-023.

\section{Correspondence adress:}

Małgorzata Futyma - Jędrzejewska, Szpital Neuropsychiatryczny ul. Abramowicka 2, 20-442 Lublin, Polska, mail: malgorzatafutyma@interia.pl.

Otrzymano: 07.06.2018

Zrecenzowano: 03.10.2018

Przyjęto do druku: 20.11.2018 